\title{
IbM PELATIHAN WEB SEKOLAH SMP MUHAMMADIYAH KEMBARAN KABUPATEN BANYUMAS
}

\author{
IbM School Website Training For SMP Muhammadiyah Kembaran, Banyumas \\ Arif Johar Taufiq ${ }^{1 *}$, Wakhyu Dwiono ${ }^{2}$, M. Taufiq Tamam ${ }^{3}$ \\ 1,2,3Program Studi Teknik Elektro, Fakultas Teknik dan Sains \\ Universitas Muhammadiyah Purwokerto \\ Jl. KH. Ahmad Dahlan, Kembaran 53182, Indonesia. \\ email: *1arifjt@gmail.com
}

\begin{abstract}
ABSTRAK
Masih banyak SMP swasta di negeri ini dengan kondisi fasilitas infrastruktur minim. Gedung kurang layak, ruang kelas apa adanya, laboratorium dan perpustakaan masih jauh dari sempurna. Untuk itu program pengabdian IbM Universitas Muhammadiyah Purwokerto menyasar kepada masyarakat dikalangan warga muhammadiyah /AUM. Dalam hal ini yang paling cepat terlihat dan tidak banyak membutuhkan banyak dana adalah pelatihan web sekolah. Program IbM pelatihan web sekolah dilakukan dengan metode workshop teori sekaligus praktek dan telah dilaksanakan dengan hasil baik, web sekolah telah tersedia, para guru telah paham tentang web, hosting, domain, serta dapat mengoperasional web sekolah.
\end{abstract}

Kata Kunci: CMS Balitbang, SMP Muhmmadiyah Kembaran, Web Sekolah.

\section{ABSTRACT}

There are still many private junior high schools in this country with minimal infrastructure facilities. Inadequate buildings, classrooms, laboratories and libraries are still far from perfect. For this reason, the IbM Muhammadiyah University of Purwokerto to service program targets the community of Muhammadiyah society/AUM. In this case the most visible and less costly way is the school's web training. The school web training IbM program is carried out using the theoretical as well as practical workshop method and has been implemented with good results, the school web is available, the teachers are familiar with web, hosting, domains, and can operate the school website.

Keywords: CMS Balitbang, SMP Muhammadiyah Kembaran, School Website.

\section{Pendahuluan}

SMP Muhammadiyah Kembaran adalah salah satu lembaga pendidikan (sekolah) yang menyelenggarakan pendidikan tingkat dasar setingkat SMP. Lembaga ini berdiri pada 1 Januari 1975 dan disahkan sebagai Sekolah Muhammadiyah dibawah asuhan Pimpinan Muhammadiyah Daerah Banyumas Majelis Pendidikan Pengajaran dan Kebudayaan pada 1 Juli 1979. Hingga saat ini status sekolah adalah terakreditasi B dengan Nomor Statistik Sekolah (NSS) : 202030222027 dan Nomor Pokok Sekolah Nasional (NPSN) : 20301867.

Jumlah siswa dari kelas 7 sampai dengan kelas 9 tahun 2019 sebanyak 44 siswa, dengan pekerjaan orangtua/walimurid sebagian besar adalah buruh. Kondisi ekonomi keluarga dari siswa SMP Muhammadiyah Kembaran sebagian besar adalah keluarga tidak mampu/menengah ke bawah sehingga tidak sedikit orangtua/wali murid yang kurang memperhatikan kebutuhan pendidikan putra-putrinya. Misalnya, orangtua kurang memperhatikan biaya SPP, biaya LKS, dan biaya seragam putranya, bahkan 
banyak yang belum melunasi administrasi sampai lulus sekolah. Akibatnya, sekolah mengalami kesulitan dalam memenuhi kebutuhan operasional sekolah. Meskipun ada dana BOS, tetapi sekolah masih belum bisa memenuhi seluruh kebutuhannya karena siswa masih sedikit sehingga dana BOS yang diterima juga sedikit, tidak seimbang dengan banyaknya pengeluaran sekolah.

SMP Muhammadiyah Kembaran memiliki tenaga guru sebanyak 10 orang, dan penjaga sekolah 1 orang. Guru dan karyawan SMP Muhammadiyah Kembaran belum sepenuhnya berstatus guru/karyawan tetap yayasan. Karena kurangnya pemasukan dari sekolah, sampai saat ini guru dan karyawan SMP Muhammadiyah Kembaran masih menerima gaji di bawah standar dengan rata-rata gaji setiap guru adalah Rp 400.000,00 per bulan. Dari ke sepuluh guru tersebut, tiga diantaranya sudah bersertifikasi.

Pendidikan di SMP Muhammadiyah Kembaran diselenggarakan dengan mengambil waktu pagi hingga siang hari dengan menggunakan gedung milik sendiri. Didukung oleh tenaga pengajar yang ratarata lulusan Strata 1 (S1) serta tenaga administrasi yang memiliki keahlian sendiri. Pendidikan yang diberikan didasarkan pada Kurikulum KTSP 2006 dan Kurikulum 2013 dengan tambahan mata pelajaran ciri khusus yaitu Al-Quran, Tarikh, Akhlaq, Ibadah, Akidah, Bahasa Arab dan Kemuhammadiyahan. Lulusan SMP Muhammadiyah Kembaran diharapkan menjadi pribadi yang berkarakter, berbudi pekerti luhur, dan berakhlak mulia.

Selain memberikan mata pelajaran sebagaimana yang ditetapkan oleh kurikulum nasional SMP Muhammadiyah Kembaran juga memberikan kegiatan ekstrakurikuler untuk melengkapi keterampilan yang dimiliki siswa, sehingga siswa tidak menerima pendidikan yang bersifat teoritis saja. Adapun ekstra kurikuler yang diberikan di SMP Muhammadiyah Kembaran antara lain: BTA, Gendingan, Hizbul Wathan, dan Tapak Suci.

Dengan kondisi yang telah dipaparkan infrastrukur yang di miliki oleh SMP Muhammadiyah sangat terbatas. Secara umum siswa dan orang tua siswa merupakan masyarakat dengan tingkat pendapatan menengah kebawah. Masih sangat dibutuhkan fasilitas peralatan penunjang seperti laboratoriuan, kebutuhan IT, dsb. Infrastruktur secara fisik dibutuhkan dana besar, sementara sumber dana terbatas. Upaya dalam waktu cepat dan tidak dibutuhkan dana yang tidak terlalu besar untuk membantu infrastruktur kebutuhan SMP Muhammadiyah adalah dari sisi teknologi informasi yaitu web sekolah. Sehingga dalam program IbM ini diangkat tema tentang teknologi informasi (web sekolah) yang dapat bermanfaat bagi sekolah sebagi salah satu kecil sumbangan dibidang infrastruktur teknologi informasi.

Kondisi infrastruktur yang sangat minim, sedikitnya jumlah siswa, dan profesi orang tua siswa yang kebanyakan berprofesi sebagai buruh dengan pendapatan kecil menjadi salah satu kendala pengembangan sekolah SMP Muhammadiyah Kembaran. Tuntutan jaman industri saat ini mau tidak mau harus melibatkan kecanggihan komputer untuk membantu proses pekerjaan. Mengejar infrastrukur fisik sangat berat bagi sekolah swasta daerah dengan jumlah siswa terbatas tersebut, padahal tuntutan masyarakat semakin tinggi. Hal ter cepat untuk mengatasi hal tersebut adalah perbaikan dari sisi teknologi informasi. Itu semua salah satu kecil untuk melangkah di era revolusi industri 4.0 diperlukan kebutuhan keahlian di bidang data, teknologi dan manusia bagi civitas akademik sekolah (M.A. Ghufron , 2018).

Permasalahan ini dapat dijawab dengan cepat dan tidak terlalu mahal salah satunya dengan membangun teknologi informasi tentang web sekolah. Setidaknya dapat membantu menyediakan informasi, data sekolah, publikasi dan komunikasi dengan masyarakat umum. Tujuan dari program pengabdian ini adalah memberikan pelatihan cara membangun web sekolah dan pengoperasiannya. Manfaat yang diharapkan adalah mempermudah proses belajar mengajar secara online. Menjembatani informasi antara sekolah, siswa, orang tua siswa dan masyarakat umum. 


\section{Metode}

Tahapan yang dilakukan untuk menyelesaikan masalah sebagai berikut:

Dari pihak tim IbM, melakukan:

a.Mencari data yang diperlukan untuk program IbM ke pihak Sekolah

b.Membuat perjanjian pelaksanaan

c. Menyiapkan alat dan bahan yang diperlukan

d.Melaksanakan program IbM yang telah disepakati

e.Memberikan layanan setelah program/pendampingan

Dari pihak mitra:

a.Memberikan data yang diperlukan

b.Membuat kesepakatan waktu pelaksanaan

c.Menyiapkan tempat dan audien

d.Melaksanakan pogram IbM bersama tim pelaksana program IbM

e.Menjalankan kesinambungan program

Kelompok sasaran Program IbM adalah guru-guru SMP Muhammadiyah Kembaran, Kecamatan Kembaran, Kabupaten Banyumas. Metode yang digunakan dalam realisasi IbM adalah pelatihan, penerapan hasil penelitian sebagaimana contoh web sekolah di daerah lainnya dalam penelitian Umi Khudhoifah (2012), yaitu pelatihan web sekolah dengan teknologi CMS Balitbang dengan cara didampingin pada saat implementasi praktek, penggisian content web, pengaturan menu dan sebagainya juga pemeliharaan setelah berjalan.

Tahapan kegiatan IbM adalah sosialisasi program, pelatihan, dan praktik langsung serta pendampingan. Sosialisasi program dilakukan melalui tatap muka untuk menyampaikan program IbM kepada mitra sasaran. Pelatihan dilakukan diawali dengan penyampaian materi disusul dengan praktek langsung serta diskusi. Pendampingan dilakukan selama proses pelatihan.

Evaluasi pelaksanaan IbM dilihat dari keberhasilan peserta dapat melaksanakan materi yang telah didapat, juga melihat keahlian peserta saat praktek langsung. Evaluasi selanjutnya adalah melihat kemajuan isi content dari web sekolah yang telah dibuat beserta menu-menu yang telah ditentukan. Pelatihan website melalui CMS ini diharapkan terjadi peningkatan literasi visual melalui isi website sebagaimana dalam (Ariaga, 2016)

\section{Hasil dan Pembahasan}

Kegiatan IbM dilapangan dimulai sejak tanggal 15 Desember 2019 dengan melakukan survey awal dan pengambilan data yang diperlukan untuk pembuatan website sekolah. Bertemu langsung dengan bapak Kepala Sekolah SMP Muhammadiyah Kembaran. Pada waktu itu telah diserahkan syarat-syarat adminstratif untuk pembelian domain dan hosting.

Pada tanggal 20 Desember 2019 tim IbM mengambil surat-surat administratif untuk diproses selanjutnya dalam pembuatan website. Tanggal 21 Desember 2019 akhirnya telah didaftarkan domain dan hosting untuk satu tahun. Proses setting dan instalasi serta pembuatan website dilakukan pada tanggal 23 Desember 2019 dan pada waktu itu masih menunggu propagasi DNS server, hasil instalasi web masih ada kesalahan.

Di hari berikutnya tanggal 24 Desember 2019 dilakukan perbaikan error pada koneksi database dengan solusi setting MySQL ke versi 5 yang compatible dengan CMS Balitbang. Hasil yang didapat koneksi database sudah normal bekerja dengan baik, tetapi masih ada error login untuk masuk ke bagian back office admin website. Solusi yang didapat adalah dengan cara masuk ke bagian phpMyAdmin melakukan reset password dengan cara tabel timpa password di table user dengan kode: 
57gc0bbbfb6b3 simpan perubahannya. Setelah itu silahkan login admin dengan password: admin [default]

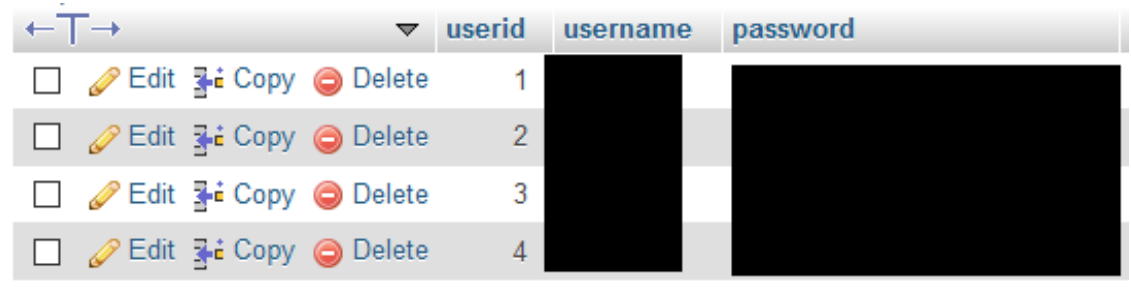

Gambar 1. Reset Tabel User

Hari Senin 6 Januari 2020 diadakan koordinasi waktu pelaksanaan pelatihan dan dan pada tanggal 13 Januari 2020 jam 10:30 WIB tempat di SMP Muhammadiyah Kembaran, dan pada tanggal tersebut telah dilakukan pelatihan website program IbM.

\subsection{Evalusi Hasil}

Setelah program berjalan dengan baik sesuai jadwal yang telah ditentukan yang diikuti oleh Guruguru SMP Muhammadiyah kembaran. Hasil yang didapat web sekolah telah berhasil dibuat dan para guru dapat mengoperasionalkan website. Pada guru telah dapat mengisi materi website sekolah sesuai harapan yang diinginkan. Tampilan website sekolah seperti terlihat pada Gambar 1. Melalui sample data pesuatif kualitatif di dapat hasil cukup baik, sebagimana ditampilkan dalam Tabel 1.

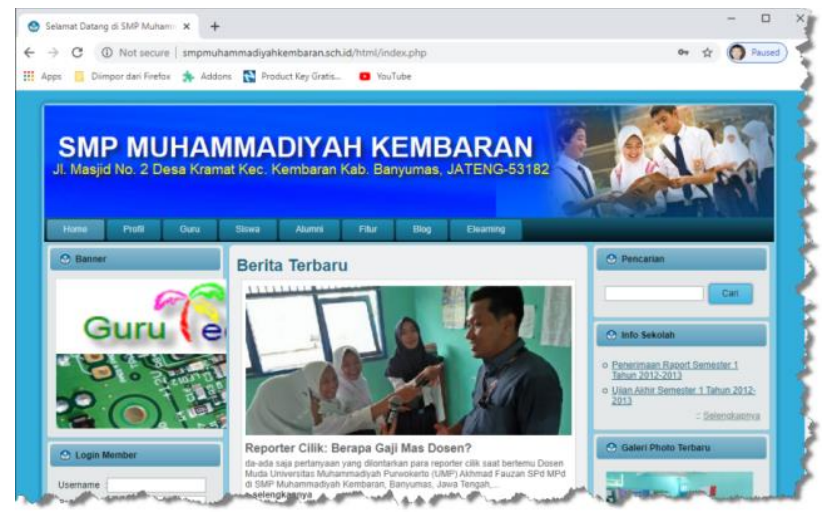

Gambar 2. Tampilan web sekolah SMP Muhammadiyah Kembaran

Hasil program pelatihan website dinyatakan pada Tabel.1 sebagai berikut

Tabel 1. Capaian program IbM

\begin{tabular}{lll}
\hline \multicolumn{1}{c}{ Pernyataan } & $\begin{array}{c}\text { Keadaan sebelum } \\
\text { IbM }\end{array}$ & \multicolumn{1}{c}{ Keadaan setelah lbM } \\
\hline Website sekolah & Tidak ada & Sudah ada \\
Pengetahuan tentang hosting & Belum paham & Sudah paham \\
Pengetahuan tentang domain & Belum paham & Sudah paham \\
Pengetahuan tentang CMS & Belum ada & Sudah ada \\
Pengoperasian website & Belum paham & Sudah paham \\
Informas ke khalayak ramai tentang sekolah & Kurang & Sudah tersedia online riil time \\
Komunitas siswa online & Tidak ada & Sudah ada \\
Komunitas guru online & Baru ada WA & Sudah ada via website sekolah \\
& & \\
\hline
\end{tabular}




\subsection{Luaran Yang diperoleh}

Luaran yang diperoleh dari program IbM ini adalah terciptanya web sekolah di alamat http://smpmuhammadiyahkembaran.sch.id, pemahaman para guru tentang hosting, domain. Buku modul panduan operasional website serta panduan instalasi website praktis web server disebuah flashdisk (telah mendapat sertifikat HAKI).

\section{Faktor Pendorong dan Penghambat}

Faktor pendorong :

1. Support dana dari LPPM UMP

2. Kesediaan mitra

3. Dukungan fasilitas dari mitra

Faktor penghampat :

1. Terbatasnya dana

2. Tidak ada SDM khusus dari pihak sekolah untuk tugas pengelolaan web kdarena terbatasanya SDM.

\section{Kesimpulan}

Dari hasil program IbM yang telah dilakukan dapat di simpulkan sebagai berikut: Website sekolah telah berhasil dibuat. Pengetahuan tentang website sekolah telah dipahami oleh guru-guru SMP Muhammadiyah Kembaran (mitra). Adanya informasi yang cepat tersebar antar guru, siswa, orang tua dan masyarakat. Program IbM telah terlaksana dengan baik

Saran yang dapat diberikan antara lain: Tetap dijaga opersional web sekolah dengan cara update isi web secara berkala. Manfaatkan penuh fasilitas web yang sudah ada

\section{UCAPAN TERIMA KASIH}

Ucapan terima kepada LPPM UMP atas didanainya program IbM ini sehingga program ini dapat terlaksana dengan baik.

\section{DAFTAR PUSTAKA}

Ariga, T., Watanabe, T., Otani, T., Masuzawa, T., (2016). Learning program for enhancing visual literacy for non-design students using a CMS to share outcomes. International Journal of Technology \& Design Education. Feb2016, Vol. 26 Issue 1, p133-148. 16p.

Hidayatullah. (2012). LKP : Rancang Bangun Company Profile Berbasis Web Menggunakan CMS di SMA Giki 2 Surabaya. Undergraduate thesis, STIKOM Surabaya

Antasari, I.W., (2017). Membuat Website/Blog Profesional sebagai Sarana Penyebaran Informasi Sekolah., Media pustakawan vol 24 No. 2.

Ghufron, M.A., (2018). Revolusilndustri4.0:Tantangan, Peluang Dan Solusi Bagi Dunia Pendidikan. Seminar Nasional dan Diskusi Panel Multidisiplin Hasil Penelitian \& Pengabdian kepada Masyarakat, Jakarta

Khudhoifah, U., (2012). Pengembangan Website Sekolah Sebagai Alternatif Sistem Informasi Sekolah Terpadu (Sifoster) Berbasis Cms Balitbang Di SMP Kesatrian 2 Semarang. Under Graduates thesis, Universitas Negeri Semarang. 